\title{
Pig BMSCs Transfected with Human TFPI Combat Species Incompatibility and Regulate the Human TF Pathway in Vitro and in a Rodent Model
}

\author{
Hongchen Jia Xiao Li $i^{a}$ Shuqiang Yue ${ }^{a}$ Junjie Lib Hui Chen ${ }^{c}$ Zhuochao Zhang ${ }^{a}$ \\ Ben Ma ${ }^{a}$ Jing Wang ${ }^{a}$ Meng Pu ${ }^{a}$ Liang Zhou ${ }^{c}$ Chong Feng ${ }^{d}$ Desheng Wanga \\ Juanli Duan ${ }^{\mathrm{a}}$ Dengke Pan ${ }^{\mathrm{d}}$ Kaishan Tao ${ }^{\mathrm{a}}$ Kefeng Dou \\ aDepartment of Hepatobiliary Surgery, Xijing Hospital, Fourth Military Medical University, Xi'an, \\ ${ }^{b}$ Department of emergency, Xijing Hospital, Fourth Military Medical University, Xi'an, 'Sichuan Academy \\ of Medical Sciences, Chendu, Institute of Animal Science of Chinese Agriculture Sciences Academy, \\ Beijing, People's Republic of China
}

\section{Key Words}

Xenotransplantation - Tissue factor/Factor VIIa - Tissue factor pathway inhibitor - Animal model $•$ Bone marrow mesenchymal stem cells

\begin{abstract}
Background: The activation of tissue factor (TF) is one of the major reasons for coagulation dysregulation after pig-to-primate xenotransplantation. Tissue factor pathway inhibitor (TFPI) is the most important inhibitor of TF. Studies have demonstrated species incompatibility between pig TFPI and human TF. Methods: A pig-to-macaque heterotopic auxiliary liver transplantation model was established to determine the origin of activated TF. Chimeric proteins of human and pig TFPI were constructed to assess the role of Kunitz domains in species incompatibility. Immortalised pig bone marrow mesenchymal stem cells transfected with human TFPI were tested for their ability to inhibit clotting in vitro. Results: TF from recipient was activated early after liver xenotransplantation. Pig TFPI Kunitz domain 2 bound human FXa, but Kunitz domain 1 did not effectively inhibit human TF/FVIIa. Immortalised pig bone marrow mesenchymal cells (BMSCs) transfected with human TFPI showed a prolonged recalcification time in vitro and in a rodent model. Conclusion: Recipient TF is relevant to dysregulated coagulation after xenotransplantation. Kunitz domain 1 plays the most important role in species incompatibility between pig TFPI and human TF, and clotting can be inhibited by human TFPI-transfected pig BMSCs. Our study shows a possible way to resolve the incompatibility of pig TFPI.
\end{abstract}

H. Ji, X. Li, S. Yue, J. Li and H. Chen contributed equally to this work.

Dou Kefeng, Tao Kaishan and Pan Dengke

\section{KARGER 125}

Department of Hepatobiliary Surgery, Xijing Hospital, Fourth Military Medical University, 15 Changle Road, Xi'an, Shaanxi 710032 (PR China); E-Mail gdwkgwx@fmmu.edu.cn, E-Mail taokaishan0686@163.com; and Institute of Animal Science of Chinese Agriculture Sciences Academy, Beijing 100000, (PR China); E-Mail pandengke2002@163.com 


\section{Cellular Physiology Cell Physiol Biochem 2015;36:233-249 \begin{tabular}{ll|l} 
and Biochemistry $\begin{array}{l}\text { DOI: 10.1159/000374067 } \\
\text { Published online: May 04, } 2015\end{array}$ & $\begin{array}{l}\text { C 2015 S. Karger AG, Basel } \\
\text { www.karger.com/cpb }\end{array}$
\end{tabular} \\ Hongchen et al.: Coagulation Dysregulation due to Xenotransplantation}

\section{Introduction}

The shortage of human donor livers limits clinical liver transplantation [1]. Xenotransplantation using transgenic pig organs may meet the increasing need for liver transplantation in humans [2]. However, coagulation disorders after liver xenotransplantation, manifested as thrombotic microangiopathy and consumptive coagulopathy, are now regarded to be the major barrier to successful liver xenotransplantations from pigs to humans [3-5].

The activation of tissue factor (TF) plays an important role in coagulation disorders after liver xenotransplantation [6-9]. However, the origin of TF in the pig-to-primate liver xenotransplantation model is controversial. In the study by Nagayasu et al. [7], pig TF was positive at the time of recipient death. In vitro studies also indicated that aortic endothelial cells were TF positive when exposed in human serum [10]. However, in Ekser's study [8], pig TF was negative in donor livers at 2 hours after transplantation, when thrombotic microangiopathy and consumptive coagulopathy began, although recipient peripheral blood mononuclear cells (PBMCs) were already human TF positive. In Lin's study of kidney xenotransplantation from pig to primate [11], although TF mRNA was positive in recipient platelets, PBMCs, and the native organs (heart and liver), it was negative on the donor organ (kidney). Lin's in vitro study also revealed that activated TF on recipient platelets and PBMCs caused dysregulation of coagulation [6]. Thus, the activation of recipient TF may be the main cause of coagulation dysregulation in the early period after liver xenotransplantation.

Tissue factor pathway inhibitor (TFPI) is the most important endogenous inhibitor of blood coagulation initiated by TF [12-14]. The $\alpha$ isoform (TFPI $\alpha$ ) has 3 Kunitz-type domains [11]. Kunitz domain 1 (K1) inhibits the Factor VIIa (FVIIa)/TF complex, and Kunitz domain 2 (K2) binds FXa. Kunitz domain 3 also plays a role in FXa binding and participates in TFPI localisation to the endothelium via a glycosylphosphatidylinositol (GPI) anchor. Another spliced form of TFPI, called TFPI $\beta$, contains only $\mathrm{K} 1$ and $\mathrm{K} 2$ and is directly attached to endothelial cells by a GPI linkage. Despite the presence of mRNA, TFPI $\beta$ protein has not directly been observed by western blot analysis in non-transfected cells [13]. Therefore, only TFPI $\alpha$ is discussed in this study. Kopp et al. [15] showed that inhibition of human TF by pig TFPI $\alpha$ is inefficient, which may partly explain coagulation dysregulation after xenotransplantation. However, Lee et al. [16] showed that recombinant pig TFPI efficiently inhibits human TF in vitro. Thus, the species incompatibility between pig TFPI and human $\mathrm{TF}$, and the role of the Kunitz domains, remains unclear.

\section{Materials and Methods}

\section{Animals}

$\mathrm{Wu}$ Zhishan miniature pigs ( $\mathrm{n}=3,18-20 \mathrm{~kg}$, males) that were genetically engineered as $\alpha-1$, 3-galactosyltransferase knockouts (GTKO) were obtained from the Institute of Animal Science of the Chinese Agricultural Sciences Academy (Beijing, China). Tibetan macaques (n=3, 23-26 kg, male) were obtained from the Sichuan Academy of Medical Sciences (Chengdu, China). The blood type of all of the pigs was $\mathrm{O}$ and that of all of the macaques was A, as determined with a human ABO blood type assay kit (Yingke, China).

All of the animals were handled according to the Ministry of Health guidelines for the care and use of laboratory animals (GB 14925-2001), and all of the procedures were approved by the Laboratory Animal Ethics Committee of the Fourth Military Medical School.

Heterotopic auxiliary liver transplantation from GTKO pigs to Tibetan macaques

A heterotopic auxiliary liver transplantation model from GTKO pigs to Tibetan macaques was established to study the cause of clotting disorders and the origin of TF. A liver graft (left lobe, weight 205$220 \mathrm{~g}$ ) was harvested from each donor pig (Fig. 1A). The graft-to-recipient weight ratios were 8.9\%, 8.3\%, and $8.5 \%$. The recipients were anaesthetised with ketamine $(15 \mathrm{mg} / \mathrm{kg})$ and xylazine $(1 \mathrm{mg} / \mathrm{kg})$ before intubation. Under isoflurane inhalation anaesthesia, a midline abdominal incision and splenectomy of the recipient was performed so that the donor graft could be placed in the splenic recess. The recipient's left 


\section{Cellular Physiology Cell Physiol Biochem 2015;36:233-249 \\ \begin{tabular}{ll|l} 
and Biochemistry & $\begin{array}{l}\text { DOI 10.1159/000374067 } \\
\text { Published online: May 04, } 2015\end{array}$ & $\begin{array}{l}\text { O 2015 S. Karger AG, Basel } \\
\text { www.karger.com/cpb }\end{array}$ \\
\cline { 2 - 3 }
\end{tabular} \\ Hongchen et al.: Coagulation Dysregulation due to Xenotransplantation}

renal vein was interrupted, the distal end was connected to the graft's portal vein, and the proximal end was connected to the graft's hepatic vein. Before reperfusion, microvascular anastomosis was performed to join the graft's hepatic artery and the recipient's splenic artery to re-establish the liver graft circulation. The bile of the donor liver was drained through the abdomen to visually assess liver graft function (Fig. 1B). After surgery, the recipients were extubated and recovered from anaesthesia. Computed tomography angiography was used to observe blood supply or donor and recipient livers 24 hours after xenotransplantation (Fig. 1C).

The immunosuppressive regimen was based on Kim et al. [17]. In brief, induction therapy was performed with 3 doses of thymoglobulin 3 days before transplantation in all cases. Cobra venom factor was used 1 day before surgery to deplete complement factors (CH50) to $5 \%$ or less of baseline levels. Immunosuppression was maintained with decreasing doses of methylprednisolone (starting at $10 \mathrm{mg} / \mathrm{kg}$ ) and tacrolimus (serum levels $10-25 \mathrm{ng} / \mathrm{ml}$ from day -1). Biopsies from both recipient and donor livers were obtained before, 2 hours after, and 48 hours after transplantation. The recipients were euthanised when the mean arterial pressure was consistently below $40 \mathrm{mmHg}$. Blood samples were analysed for routine blood tests, chemistry, tacrolimus serum levels, and coagulation. All of the tests were performed once a day (and on other occasions as needed) in the clinical laboratory of Xijing Hospital.

\section{Cell culture}

Aortic endothelial cells (AECs) were harvested from GTKO pigs and cultured in $2 \%$ gelatin-coated tissue culture flasks with RPMI 1640 (HyClone, USA) containing 10\% foetal bovine serum (FBS, HyClone, Logan, UT, USA), penicillin (0.5\%), streptomycin (0.5\%), and L-glutamine $(2 \mathrm{mM})$ at $37{ }^{\circ} \mathrm{C}$ in $5 \% \mathrm{CO}_{2}[16]$. Pig AECs were passaged six or fewer times for all of the experiments.

Pig bone marrow mesenchymal stem cells (BMSCs) were separated from the bone marrow of the spina iliaca of GTKO pigs and purified by density gradient centrifugation. Purified pig BMSCs were incubated in Dulbecco's modified Eagle medium/nutrient mixture F-12 (DMEM/F12, HyClone) containing 15\% FBS, penicillin $(0.5 \%)$, and streptomycin $(0.5 \%)$ at $37^{\circ} \mathrm{C}$ in $5 \% \mathrm{CO}_{2}$.

\section{In vitro model to induce the expression of human and pig TF}

Adherent pig AECs and monocytes were pre-incubated with 5\% human plasma for 8 hours to induce the expression of pig or human TF, respectively, on the cell surface $[5,18,19]$. Human plasma was drawn from volunteers with type A blood. After co-incubation, monocytes were isolated by centrifugation and AECs were harvested using $0.5 \%$ trypsin (Gibco, UK). For some tests, pig AECs or human monocytes were co-incubated with pig BMSCs, anti-TF (catalogue no. 17375, Abcam, USA), or TFPI for further studies.

\section{Construction, expression, and purification of chimeric proteins}

The pig TFPI sequence (NM_001135258.1) and human TFPI sequence (NM_006287.4) were obtained from GenBank. The TFPI sequence from Wu Zhishan miniature GTKO pigs was reported in Fang et al. [20]. TFPI sequences were compared using ClustaX2 software. The sequencing of all of the chimeric proteins, pig TFPI, and human TFPI was performed with molecular cloning, and the fragments were inserted into the pIRES2-EGFP expression vector (BD Biosciences Clontech, USA). A His tag was added to the C-terminus of chimeric and recombinant protein sequences for purification.

Chimeric proteins, recombinant human TFPI, and recombinant pig TFPI were expressed in E. coli BL21 cells. Isopropyl $\beta$-D-thiogalactoside $(0.2 \mathrm{mM})$ was used to induce expression at $22{ }^{\circ} \mathrm{C}$ for 8 hours. Fusion proteins were purified with a $\mathrm{Ni}^{2+}$-nitrilotriacetate agarose resin (Qiagen, Germany), characterised by SDSPAGE, and verified by western blotting.

\section{TFPI activity assay}

An actichrome TFPI activity assay kit (American Diagnostica, USA) was used to determine the activity of recombinant pig TFPI, recombinant human TFPI, and chimeric TFPI by measuring FX activation by the FVIIa/TF complex. Human FVIIa/TF $(20 \mu \mathrm{l})$ was mixed with each source of TFPI $(2.5 \mathrm{nM})$ and incubated at $37^{\circ} \mathrm{C}$ for 30 minutes. Human FX (20 $\mu$ l, Merck Millipore, USA) was then added to the mixture and incubated another 15 minutes at $37^{\circ} \mathrm{C}$. EDTA $(20 \mu \mathrm{l})$ was added to terminate the reaction. Chromogenic detection was carried out using a highly specific chromogenic FXa substrate (American Diagnostica, Greenwich, CT, USA), and absorbance was measured at $405 \mathrm{~nm}$. TFPI activity was determined by comparison with a standard curve generated using known concentrations of recombinant human TFPI in a $20-\mu \mathrm{l}$ volume. 


\section{Cellular Physiology Cell Physiol Biochem 2015;36:233-249 \begin{tabular}{ll|l} 
and Biochemistry & $\begin{array}{l}\text { DOI: 10.1159/000374067 } \\
\text { Published online: May 04, } 2015\end{array}$ & $\begin{array}{l}\text { O 2015 S. Karger AG, Basel } \\
\text { www.karger.com/cpb }\end{array}$ \\
\cline { 2 - 3 }
\end{tabular}}

Hongchen et al.: Coagulation Dysregulation due to Xenotransplantation

For assays of total cellular TFPI, cells were harvested with trypsin and lysed with 30 mM CHAPS (Amresco, Solon, OH, USA). Total protein was determined using the BCA protein assay (Pierce, Rockford, IL, USA). Harvested cells were homogenised with a Brinkman Polytron homogeniser on ice and subjected to three freeze/thaw cycles in the presence of $1 \mathrm{mM}$ 1-(L-transepoxysuccinylleucylamino)-4-guanidinobutane (E-64, Sigma, St Louis, MO, USA). Cellular lysates were treated with $1 \mathrm{U} / \mathrm{ml}$ phosphatidylinositol-specific phospholipase C (PIPLC) for 1 hour at $37^{\circ} \mathrm{C}$. TF was removed by centrifugation at 436,000 $\times \mathrm{g}$ for 3 hours at $4{ }^{\circ} \mathrm{C}$. TFPI activity was then determined as described by Mast et al. [14]. In some tests, the cells were preincubated with anti-human TFPI. All of the experiments were repeated three times.

\section{FXa binding assay}

The capacity of TFPI binding and the generation of thrombin initiated directly by FXa were determined as described [21]. Briefly, phospholipids (400 $\mu \mathrm{M}, 75 \%$ phosphatidylcholine, 25\% phosphatidylserine vesicles, Sigma), co-factors (20 nM FV), and zymogens (5.6 $\mu$ M prothrombin, $360 \mathrm{nM}$ FIX, $680 \mathrm{nM}$ FX) were incubated in $20 \mathrm{nM}$ HEPES ( $\mathrm{pH} 7.4$ ) containing $150 \mathrm{nM} \mathrm{NaCl}$ and $2 \mathrm{mM} \mathrm{CaCl}_{2}$. Prothrombin and coagulation factors were purchased from Merck Millipore (Germany). Immediately after mixing the phospholipids, cofactors, and zymogens with $2.5 \mathrm{nM}$ of the desired source of TFPI (or no TFPI), FXa was added to initiate thrombin generation. The chromogenic substrate Spectrozyme TH $(0.2 \mathrm{mM}$, American Diagnostica) was added to detect thrombin activity, and absorbance was measured at $405 \mathrm{~nm}$. The concentration of prothrombinase was calculated from the rate of thrombin generation using a $k_{\text {cat }}$ of $5016 /$ minute. The inhibition of prothrombinase by TFPI was calculated by comparison with the control group carried out in the absence of TFPI. All of the experiments were repeated three times.

\section{Recalcification assay}

Human and macaque PBMCs were prepared by Ficoll-Hypaque density gradient centrifugation. After blood was diluted with the same volume of PBS, $10 \mathrm{ml}$ of blood preparation was overlaid on 15 ml FicollHypaque (AppliChem GmbH, Germany). Centrifugation at $700 \times \mathrm{g}$ was then performed to separate the buffy coat. The separated buffy coat interface was then added to $10 \mathrm{ml}$ PBS and centrifuged at $300 \times \mathrm{g}$. After, the cells were suspended in $\alpha$-MEM (HyClone, USA) containing $0.1 \%$ BSA. Human monocytes were selected from PBMCs by anti-human CD14 magnetic beads (Miltenyi Biotec, Auburn, CA, USA) and macaque monocytes were selected by anti-nonhuman primate CD14 magnetic beads (Miltenyi Biotec, Auburn, CA, USA). In brief, the cells were incubated with microbeads at $4{ }^{\circ} \mathrm{C}$ for 15 minutes, washed with MACS buffer, suspended and at last loaded on the top of a separation column. CD14+ cells were then selected using cold MACS buffer, centrifuged and resuspended in $\alpha$-MEM (HyClone, USA) containing $0.1 \%$ BSA [8].

Pig AECs $\left(1 \times 10^{5}\right)$, human monocytes or recipient monocytes $\left(1 \times 10^{5}\right)$, or pig BMSCs $\left(1 \times 10^{5}\right)$ were suspended in $50 \mu \mathrm{l}$ Tris-buffered saline. Normal human plasma (100 $\mu$ l, Sigma-Aldrich) was mixed with one cell type or a combination of cells in a glass tube (Corning, NY, USA). $\mathrm{CaCl}_{2}$ (250 nM in $10 \mu$ l Tris-buffered saline) and phospholipids $(90 \mu \mathrm{l})$ were added. The tubes were agitated by continuous tilting, and the time required to form a fibrin clot was recorded. In some tests, the cells were pre-incubated with anti-human TF $(1 \mathrm{mg} / \mathrm{ml})$ or different sources of TFPI $(2.5 \mathrm{nM})$ at $4{ }^{\circ} \mathrm{C}$ for 30 minutes before the recalcification assay.

\section{Flow cytometry analysis}

To identify BMSC surface antigens, $1 \times 10^{5}$ harvested cells were incubated in PBS containing $0.1 \%$ ChromPure pig IgG (catalogue no. 136756, Abcam, USA) and $1 \% \mathrm{NaN}_{3}$ on ice for 30 minutes. The following primary monoclonal antibodies were incubated with the cells for 30 minutes at $4{ }^{\circ} \mathrm{C}$ : anti-pig CD29 (catalogue no. 21845, Abcam, USA), anti-pig CD34 (catalogue no. 61737, GeneTex, USA), anti-pig CD45 (catalogue no. 28085, Abcam, USA), anti-pig CD105 (catalogue no.53318, Abcam, USA), anti-pig CD80 (catalogue no. 110801-82, Sino biological, USA), anti-pig CD90 (catalogue no.124527, Abcam, USA) and sheep anti-human TF (Affinity Biologicals, Canada). The cells were then washed with cold FACS buffer, suspended in $350 \mu$ FACS buffer, and analysed on a dual-laser FACS Calibur (BD Biosciences, USA).

\section{Atomic force microscopy (AFM)}

Intermolecular forces were measured by AFM on a PicoSPM 5500 (Agilent Technologies, USA). AFM tips (MSCT, $\mathrm{Si}_{3} \mathrm{~N}_{4}$, Veeco, USA) were functionalised with $\mathrm{RCA}_{120}$. The thermal-noise mode was used to determine the spring constants of cantilevers. All of the experiments were performed in PBS with $1 \mathrm{mM}$ 


\section{Cellular Physiology Cell Physiol Biochem 2015;36:233-249 \begin{tabular}{l|l} 
and Biochemistry Published online: May 04, 2015 & $\begin{array}{l}\text { DC 2015 S. Karger AG, Basel } \\
\text { www.karger.com/cpb }\end{array}$ \\
\hline
\end{tabular} \\ Hongchen et al.: Coagulation Dysregulation due to Xenotransplantation}

$\mathrm{CaCl}_{2}$ and $0.5 \mathrm{mM} \mathrm{MgCl}_{2}$. We collected more than 2000 force-distance cycles from different locations with each functionalised AFM tip. Matlab Version 7 (Math works, USA) was used to analyse the force-distance cycles.

\section{Immunohistochemistry}

The slides of BMSCs and histological liver sections were fixed with $4 \%$ paraformaldehyde and then incubated with the following primary antibodies at $4{ }^{\circ} \mathrm{C}$ overnight: mouse anti-human TFPI (catalogue no. 180619, Abcam), anti-human TF (catalogue no. 17375, Abcam), and anti-pig TF (raised against a synthetic peptide with the sequence IMRNVKETYV, which is present in pig TF). After washing, the sections were incubated with the appropriate secondary antibodies for 1 hour at room temperature. Nuclei were stained with 4, 6-diamidino-2-phenylindole (DAPI) and washed three times with PBS. Finally, the sections were mounted with Permount mounting medium (National Diagnostics, USA). Images were viewed with a Leica DM 750 light microscope (Leica, Germany).

\section{Cell proliferation assay}

A methyl thiazolyl tetrazolium (MTT) assay was used to determine cell proliferation. Primary and SV40T-transfected BMSCs were seeded at $3 \times 10^{4}$ cells $/ \mathrm{ml}$ in triplicate wells of 96 -well plates. Every 24 hours, $10 \mu \mathrm{l}$ MTT ( $5 \mathrm{mg} / \mathrm{ml}$, Sigma) was added to each well, and the cells were incubated for an additional 4 hours at room temperature. The supernatant was removed, and $150 \mu \mathrm{l}$ DMSO was added to each well to solubilise the formazan crystals. The absorbance at $570 \mathrm{~nm}$ was measured on a microtitre plate spectrophotometer (BioTeck, USA).

Osteogenic and adipogenic differentiation of BMSCs

Pig BMSCs were seeded at $5 \times 10^{4}$ cells/well in 24-well plates containing osteogenic differentiation medium (Invitrogen, USA) or adipogenic differentiation medium (Invitrogen) for 28 days. The medium was changed every 48 hours. Following adipogenic differentiation, the cells were fixed with $4 \%$ paraformaldehyde and washed with double-distilled water. Lipid droplets were stained with $0.5 \%$ oil red-0 in isopropanol for 20 minutes. The cells were washed with $60 \%$ isopropanol and double-distilled water and then observed under a light microscope. Following osteogenic differentiation, the cells were fixed at $4{ }^{\circ} \mathrm{C}$ in cold methanol and washed with DPBS without $\mathrm{Ca}^{2+}$ and $\mathrm{Mg}^{2+}$. The cells were stained with $5 \%$ silver nitrate and exposed to ultraviolet light for 1 hour. The cells were washed with double-distilled water and incubated with $5 \%$ sodium thiosulphate for 2 minutes. The staining of calcium nodules was observed with a light microscope.

Quantitative reverse-transcription polymerase chain reaction (RT-PCR)

Total RNA was extracted from each sample, and $3 \mu \mathrm{g}$ were used for first-stand cDNA synthesis with oligo (dT) and Superscript III (Invitrogen). SYBR Green PCR Master Mix (Applied Biosystems) was used for PCR mixtures. The following primers were used [16, 22]:

SV40 T sense: $\quad 5^{\prime}$-CAAAGTGTGGTATGGCTGAT- ${ }^{\prime}$

SV40 T antisense: $\quad 5^{\prime}$-GGCTACTGGGAACTGGA-3'

Human TFPI sense: $\quad 5^{\prime}$-GAATTCAAATAAGGCTGCGTA-3'

Human TFPI antisense: $\quad 5^{\prime}$-GAGGGAGCCTCAGAGTCGGCTTC-3'

Primate $\beta$-actin sense: $\quad 5^{\prime}$-CGGGAAATCGTGCGTGAC $-3^{\prime}$

Primate $\beta$-actin antisense: $\quad 5^{\prime}$-TGGAAGGTGGACAGCGAGG-3'

Pig $\beta$-actin sense: $\quad 5^{\prime}$-CTCGATCATGAAGTGCGACTG-3'

Pig $\beta$-actin sense: $\quad 5^{\prime}$-GTGATCTCCTTCTGCATCCTGTC- ${ }^{\prime}$

Pig TF sense 5'-TTTACCAACTCGCCCCCCTTC -3'

Pig TF antisense: $\quad 5^{\prime}$-AATGTGCCGTTCACCCTGACTAAG $-3^{\prime}$

Primate TF sense: $\quad 5^{\prime}$-GGAACCCAAACCCGTCAATC- $3^{\prime}$

Primate TF antisense: $\quad 5^{\prime}$-TCCGAGGTTTGTCTCCAGGT-3'

Chimeric proteins were amplified with the same primers as pig TFPI. AmpliTaq Gold DNA polymerase was activated for 10 minutes at $95^{\circ} \mathrm{C}$, and amplification was performed for 40 cycles of $95^{\circ} \mathrm{C}$ for 15 seconds and $60^{\circ} \mathrm{C}$ for 1 minute on a Multicolour Real-time PCR detection system IQ 5 (Bio-Rad, USA). All of the tests were repeated three times. 


\section{Cellular Physiology Cell Physiol Biochem 2015;36:233-249 \begin{tabular}{l|l} 
DOI: 10.1159/000374067 & (C) 2015 S. Karger AG, Basel
\end{tabular} \\ Hongchen et al.: Coagulation Dysregulation due to Xenotransplantation}

Table 1. Graft type, immunosuppressive therapy, anticoagulants, anti-inflammatory agent, outcome and cause of death/euthanasia in pig to Tibetan macaques liver xenotransplantation

\begin{tabular}{|c|c|c|c|c|c|c|}
\hline$\#$ & $\begin{array}{l}\text { Type } \\
\text { of pig }\end{array}$ & $\begin{array}{l}\text { Immunosuppressive } \\
\text { therapy }\end{array}$ & anticoagulants & anti-inflammatory agent & $\begin{array}{l}\text { Survival } \\
\text { (hours) }\end{array}$ & $\begin{array}{l}\text { Cause of death } \\
\text { / euthanasia }\end{array}$ \\
\hline$\overline{\mathrm{ZHQ01}}$ & GTKO & $\begin{array}{l}\text { TAC, MMF, ATG, Anti- } \\
\text { CD154 mAb, CVF }\end{array}$ & salviae miltiorrhizae & methylprednisolone & 52 & $\begin{array}{l}\text { Pulmonary edema caused } \\
\text { by fluid overload }\end{array}$ \\
\hline ZHQ03 & GTKO & $\begin{array}{l}\text { TAC, MMF, ATG, Anti- } \\
\text { CD154 mAb }\end{array}$ & salviae miltiorrhizae & methylprednisolone & 326 & pulmonary infection \\
\hline ZHQO4 & GTKO & $\begin{array}{l}\text { TAC, MMF, ATG, Anti- } \\
\text { CD154 mAb, CVF }\end{array}$ & salviae miltiorrhizae & methylprednisolone & 116 & $\mathrm{CC}$ \\
\hline
\end{tabular}

\section{Lentiviral transfection}

The TFPI sequence was inserted into the pGMLV-PA5 expression vector. Cells were seeded at $2 \times 10^{4}$ cells/well in 24-well plates and incubated at $37{ }^{\circ} \mathrm{C}$ for 24 hours. The medium was removed and replaced with $1 \mathrm{ml}$ DMEM containing $2 \times 10^{5}$ (SV40T) or $5 \times 10^{5}$ (TFPI) lentiviral particles per well. SV40T transfection was screened using $2 \mathrm{ng} / \mathrm{ml}$ puromycin.

\section{Mouse activation of coagulation model}

The mouse activation model was described by Sparkenbaugh et al. [23]. In total, $35 \mu \mathrm{M} / \mathrm{kg}$ haeme (Sigma Aldrich, St. Louis, MO) was injected into mice to induce an activation of coagulation. Three hours later, pig BMSCs, lentiviral vector transfected pig BMSCs or human TFPI-transfected pig BMSCs were injected into mice via the tail vein $\left(2.5 \times 10^{8} / \mathrm{kg}\right.$ cells were used). A recalcification assay for mouse plasma was then performed. Mice injected with normal saline were used as controls.

\section{Western blotting}

Blots were immunostained with anti-human TFPI and an appropriate secondary antibody conjugated to horseradish peroxidase. Chemiluminescence was used to visualise labelled proteins.

Statistics

The statistical tests were performed using SPSS 19 (IBM, USA). All of the results are presented as the mean \pm standard deviation. Differences between two groups were determined with the t-test and were considered significant at $\mathrm{P}<0.05$.

\section{Results}

Recipient TF, rather than donor TF, is activated early after liver xenotransplantation

GTKO pig-to-Tibetan macaque heterotopic auxiliary liver transplantation was used to study the origin of activated TF. The immunosuppression, anticoagulation anti-inflammatory agents and cause of death/euthanasia were listed in Table 1 . In the presence of a donor liver and recipient liver, all of the recipients developed consumptive coagulopathy within 2 hours after reperfusion, as observed by the presence of thrombocytopenia, thrombin-antithrombin (TAT) complexes, and fibrin. Platelet counts fell from $325 \pm 24$ to $122 \pm 20 \times 10^{9} / 1$ at 2 hours after transplantation and continued to decrease rapidly. TAT complexes increased rapidly from $9 \pm 1$ to $186 \pm 32 \mathrm{mg} / \mathrm{l}$ at 2 hours after reperfusion and remained high until 48 hours after transplantation. The fibrinogen level decreased continuously throughout the experiment (Fig. 2A).

Immunohistochemistry was performed to detect $\mathrm{TF}$ expression in recipient and donor livers. At both 2 and 48 hours after transplantation, primate $\mathrm{TF}$ was negative in donor liver but positive in recipient liver, and pig TF was negative in both (Fig. 2B). RT-PCR showed that TF mRNA in both donor liver and recipient liver was significantly upregulated at 2 hours, 48 hours and at the time of euthanasia (Fig. 3A) compared to before transplantation. However, it was calculated that from pre-transplantation to 2 hours post-transplantation, 
Fig. 1. Heterotopic auxiliary liver transplantation from GTKO pigs to Tibetan macaques.(A) A liver graft harvested from a pig donor. (B) Surgical steps. i: splenectomy, ii: interruption of the left renal vein, iii: liver graft, iv: reconstruction of graft circulation, $\mathrm{v}$ : magnified image of vascular anastomosis, vi: biliary drainage of the donor liver. For vessels, red = artery, blue = vein, purple =portal vein. (C) Computed tomography angiogram showing good blood supply 24 hours after transplantation.
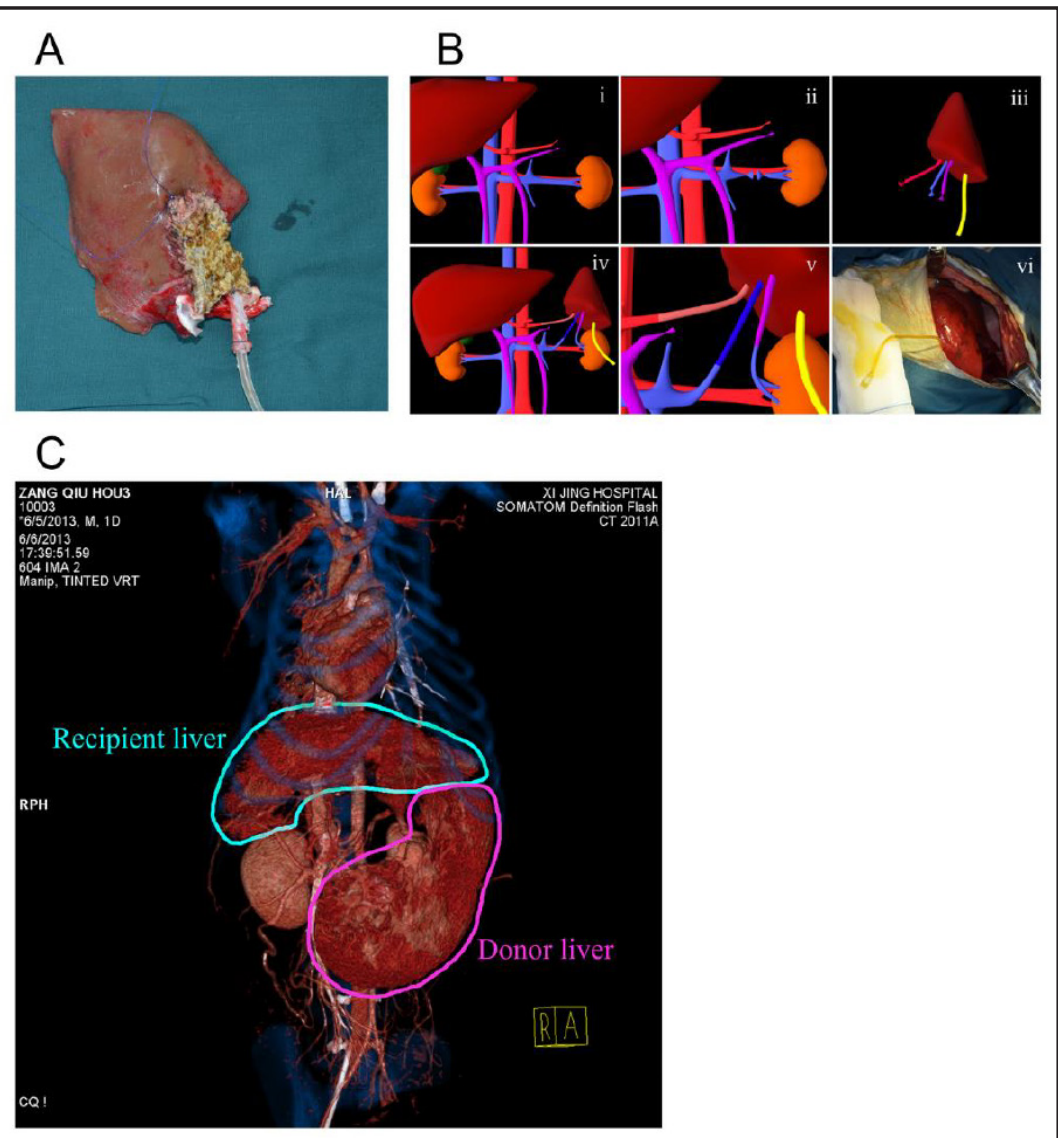

pig TF mRNA was elevated $1.42 \pm 0.15$-fold in donor liver, and primate TF was elevated 2.10 \pm 0.24 -fold in recipient liver ( $\mathrm{t}=4.162, \mathrm{P}=0.014, \mathrm{n}=3$, Fig. 3B). A significant up regulation was also observed in recipient heart and kidney (heart: $81.4 \pm 31.4$ vs. $16.7 \pm 6.6, t=2.852, P=0.046$, $\mathrm{n}=3$; kidney: $44.1 \pm 10.6$ vs. $11.6 \pm 6.5, \mathrm{t}=3.694, \mathrm{P}=0.021, \mathrm{n}=3$, Fig. $3 \mathrm{C}$ ). Recalcification assays showed that the clotting time with recipient PBMCs after transplantation (190 \pm 49 seconds) was significantly shorter than before transplantation $(627 \pm 53$ seconds, $t=10.49, P=0.001$, $n=3$, Fig. 3D).

Pig TFPI does not block the human TF pathway as effectively as human TFPI

To determine the effect of pig and human TFPI on human TF, pig AECs and human monocytes were co-cultured for 8 hours. Human monocytes were human TF positive after co-incubation (Fig. 4A). The monocytes were separated from human plasma and used for the recalcification clotting assay. Human monocytes were pre-treated with recombinant human TFPI, pig TFPI, or anti-human TF. Pig TFPI did not inhibit clotting as efficiently as human TFPI ( $239 \pm 26$ vs. $301 \pm 14$ seconds, respectively, $\mathrm{t}=2.976, \mathrm{P}=0.041, \mathrm{n}=3$, Fig. $4 \mathrm{~B})$. In the TFPI activity assay, pig TFPI did not inhibit human TF as efficiently as human TFPI (Fig. 4C).

Pig TFPI Kunitz domain 2 binds human FXa effectively, but Kunitz domain 1 does not inhibit human TF/FVIIa

TFPI inhibits the activation of TF in two sequential steps. First, Kunitz domain 2 of TFPI binds FXa. Second, Kunitz domain 1 of TFPI binds and inhibits the TF/FVIIa complex. We compared TFPI sequences in Wu Zhishan miniature pigs, large white pigs, and humans. We found that the two pig strains had the same coding sequence, and it was $96.6 \%$ similar to the human coding sequence. To study the exact roles of the three Kunitz domains of pig TFPI in species incompatibility, we next constructed three chimeric proteins using individual human 
Fig. 2. TF in donor liver activated early after liver xenotransplantation. (A) TAT complexes, fibrinogen, and platelet counts 24 hours before and after transplantation $(\mathrm{t}=$ 0 hours). (B) TF immunohisto chem is try of human and pig $\mathrm{TF}$ in donor and recipient livers before, 2 hours after, and 48 hours after transplantation.

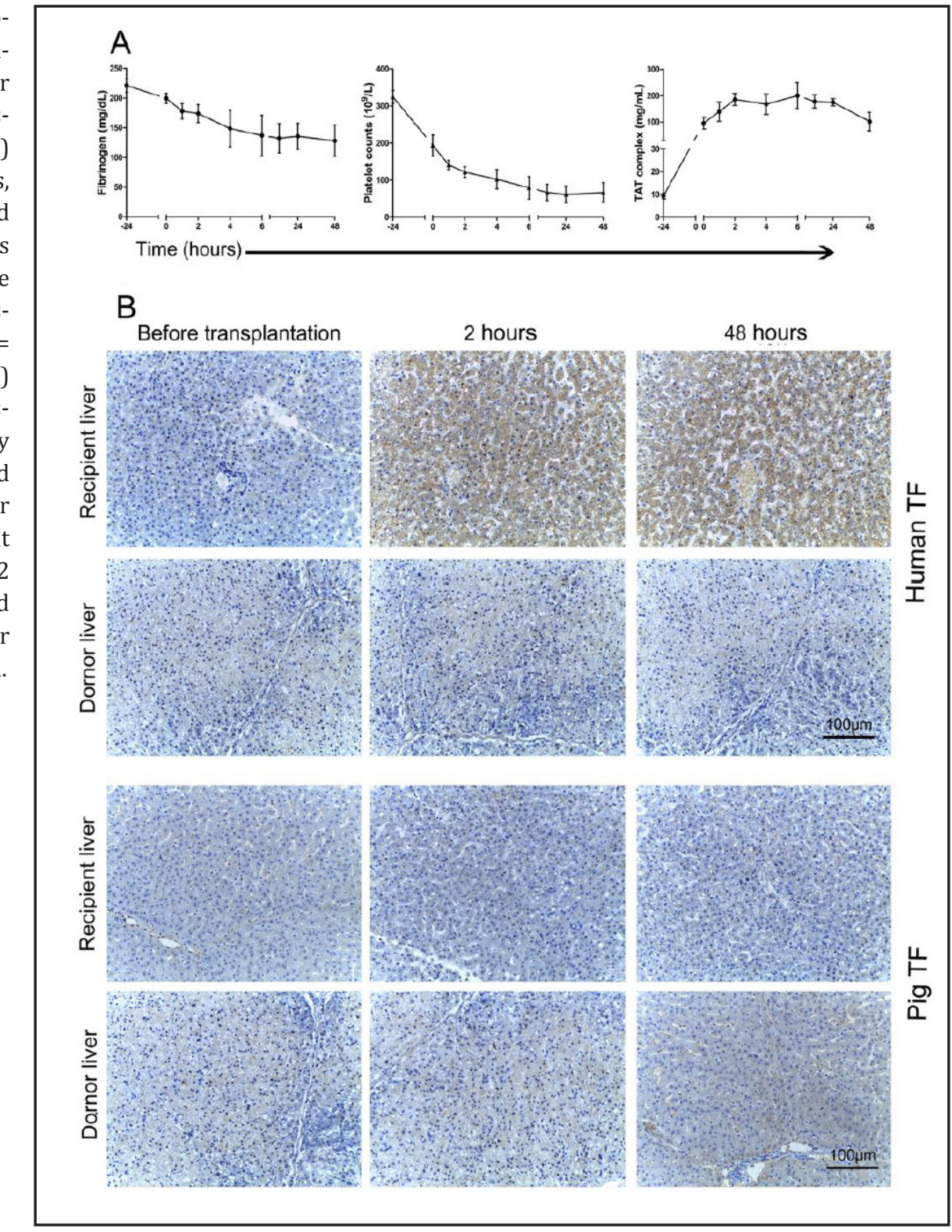

Kunitz domains to replace the corresponding pig domains. These chimeric proteins, in which human Kunitz domain 1, 2, or 3 replaced the corresponding pig Kunitz domain, were named pig TFPI ${ }_{\mathrm{hK} 1}, \mathrm{TFPI}_{\mathrm{hK} 2}$, and TFPI ${ }_{\mathrm{hK} 3}$, respectively (Fig. 5A). All of the chimeric proteins were constructed using standard molecular biological techniques and were verified by western blotting (Fig. 5B).

Pig TFPI ${ }_{\mathrm{hK} 1}$, TFPI $_{\mathrm{hK} 2}$, and TFPI ${ }_{\mathrm{hK}}$, human TFPI, and pig TFPI were analysed for their ability to bind FXa and inhibit TF/FVIIa. In the FXa binding assay, in which thrombin generation was initiated directly by FXa, different sources of TFPI bound FXa similarly (Fig. 6A). However, AFM measurements showed that the intermolecular force between pig TFPI and human FXa (69 pN) was weaker than that between human TFPI and human FXa (91 pN, Fig. 6B). In the TFPI activity assay, the inhibition of human TF/FVIIa by pig $\mathrm{TFPI}_{\mathrm{hK} 1}$ was similar to that of human TFPI, whereas pig $\mathrm{TFPI}_{\mathrm{hK} 2}, \mathrm{TFPI}_{\mathrm{hK} 3}$, and pig TFPI all had reduced inhibition (Fig. $6 C)$. In the human plasma recalcification assay, pig TFPI ${ }_{\text {hK1 }}$ inhibited TF/FVIIa well $(290 \pm 14$ seconds) and was similar to recombinant human TFPI (298 \pm 24 seconds, $\mathrm{t}=0.499, \mathrm{P}=0.644$, $\mathrm{n}=3)$, and both were significant compared with pig TFPI-treated human monocytes $(236 \pm 24$ seconds; human TFPI: $\mathrm{t}=3.164, \mathrm{P}=0.034, \mathrm{n}=3$; pig $\mathrm{TFPI}_{\mathrm{hK} 1}: \mathrm{t}=3.366, \mathrm{P}=0.028, \mathrm{n}=3$ ). Pig $\mathrm{TFPI}_{\mathrm{hK} 2}$ 
Fig. 3. Recipient TF activated after xenotransplantation(A) TF mRNA in the recipient (primate $\mathrm{TF}$ ) and donor (pig TF) livers at different times after xenotransplantation (closed bar: recipient liver; open bar: donor liver, TX = transplantation). (B) Fold increase in TF mRNA in recipient (primate TF) and donor (pig TF) livers 2 hours after transplantation. (C) TF mRNA in native heart and kidney after xenotransplantation (Tibetan macaques without surgery were used as controls). (D) The recalcification time of normal human plasma and recipient monocytes before and 2 hours after transplantation. $\quad\left({ }^{*} \mathrm{p}<0.05\right.$ vs. before transplantation or control, ${ }^{* *} \mathrm{p}<0.05$ vs. donor liver).

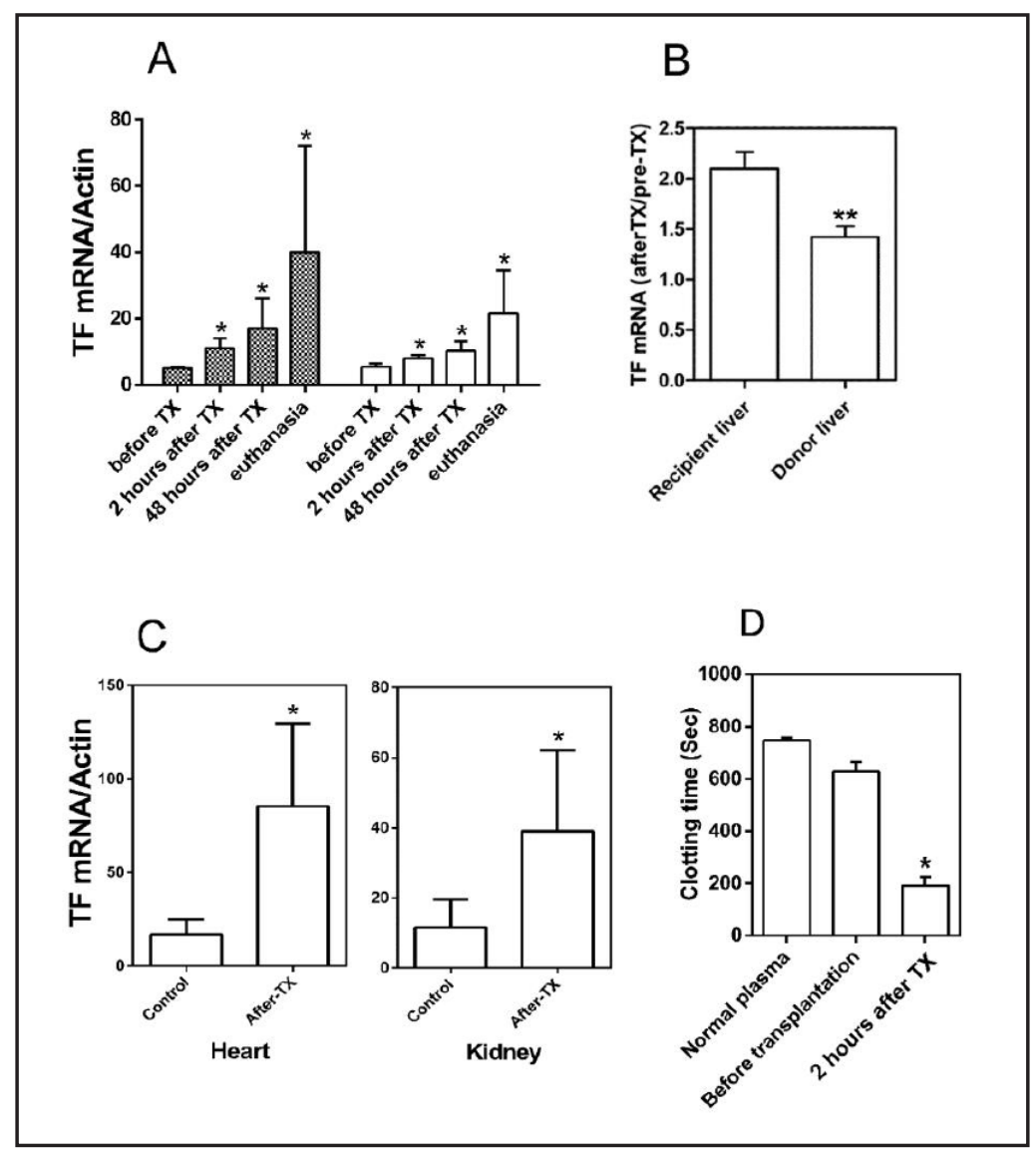

and Pig TFPI ${ }_{\mathrm{hK} 3}$ demonstrated a weaker inhibition of TF/FVIIa than did human TFPI (TFPI ${ }_{\mathrm{hK} 2}$ : $246 \pm 19$ seconds, $\mathrm{t}=2.942, \mathrm{P}=0.042, \mathrm{n}=3$; $^{\mathrm{TFPI}}{ }_{\mathrm{hK} 3}: 240 \pm 15$ seconds, $\mathrm{t}=3.550, \mathrm{P}=0.024, \mathrm{n}=3$, Fig. 6D).

To confirm the effect of different Kunitz domains on the species incompatibly of pig TFPI, the TFPI activity assay and recalcification assay were repeated with TFPI using pig Kunitz domains to replace the corresponding human domains (human TFPI ${ }_{\mathrm{pK} 1}$, human TFPI ${ }_{\mathrm{pK} 2}$ and human TFPI $_{\mathrm{pK} 3}$ ). In the TFPI activity assay, human TFPI ${ }_{\mathrm{pK} 2}$ and human TFPI ${ }_{\mathrm{pK} 3}$ inhibited the activation of TF/FVIIa well and prolonged clotting time, similar to human TFPI whereas human $\mathrm{TFPI}_{\mathrm{pK} 1}$ had reduced inhibition (Fig. 6E). In the human plasma recalcification assay, both human TFPI ${ }_{\mathrm{pK} 2}\left(290 \pm 15\right.$ seconds) and human TFPI ${ }_{\mathrm{pK} 3}(300 \pm 36$ seconds) inhibited TF/ FVIIa well and were similar to recombinant human TFPI $\left(292 \pm 22\right.$ seconds, human TFPI ${ }_{\mathrm{pK} 2}$ : $\mathrm{t}=0.130, \mathrm{P}=0.903, \mathrm{n}=3$; human $\mathrm{TFPI}_{\mathrm{pK} 3}: \mathrm{t}=0.365, \mathrm{P}=0.734, \mathrm{n}=3$ ), and both were significant compared with pig TFPI-treated human monocytes $\left(226 \pm 31\right.$ seconds; human TFPI ${ }_{\mathrm{pK} 2}$ : $\mathrm{t}=3.219, \mathrm{P}=0.032, \mathrm{n}=3$; human $\left.\mathrm{TFPI}_{\mathrm{pK} 3}: \mathrm{t}=2.924, \mathrm{P}=0.043, \mathrm{n}=3\right)$. Human $\mathrm{TFPI}_{\mathrm{pK} 1}(235 \pm 25$ seconds) demonstrated a weaker inhibition of TF/FVIIa than human TFPI ( $\mathrm{t}=2.965, \mathrm{P}=0.041$, $\mathrm{n}=3$ ) but was similar to pig TFPI ( $\mathrm{t}=0.391, \mathrm{P}=0.715, \mathrm{n}=3$, Fig. $6 \mathrm{~F}$ ).

Immortalised pig BMSCs have the same characteristics as primary cells

Based on the above results, recipient TF is important in coagulation dysregulation after pig-to-primate xenotransplantation but is not effectively inhibited by donor TFPI. Thus, we developed pig BMSCs that overexpress human TFPI and can be co-transplanted in future pig-to-primate xenotransplantation. First, primary pig BMSCs were obtained from GTKO pig bone marrow and immortalised by transfection with SV40T. SV40T/ $\beta$-actin mRNA in SV40T-transfected BMSCs $(1.067 \pm 0.193)$ was much higher than in primary or lentiviral vector transfected cells (primary cells: $0.063 \pm 0.042, \mathrm{t}=11.370, \mathrm{P}<0.001, \mathrm{n}=3$; lentiviral vector transfected cells: $0.075 \pm 0.038, \mathrm{t}=11.280, \mathrm{P}<0.001, \mathrm{n}=3$; Fig. $7 \mathrm{~A}$ ). Immortalised 
Fig. 4. Pig TFPI does not inhibit the human TF pathway as effectively as human TFPI.(A) Monocytes were TF positive after co-incubation with pig AECs. (B) The clotting times of recalcified human plasma in the presence of control monocytes or monocytes pre-treated with recombinant human TFPI, recombinant pig TFPI, or anti-human TF antibody. (C) Measurement of endogenous tissue factor activity for recombinant human TFPI, recombinant pig TFPI, and no TFPI control.
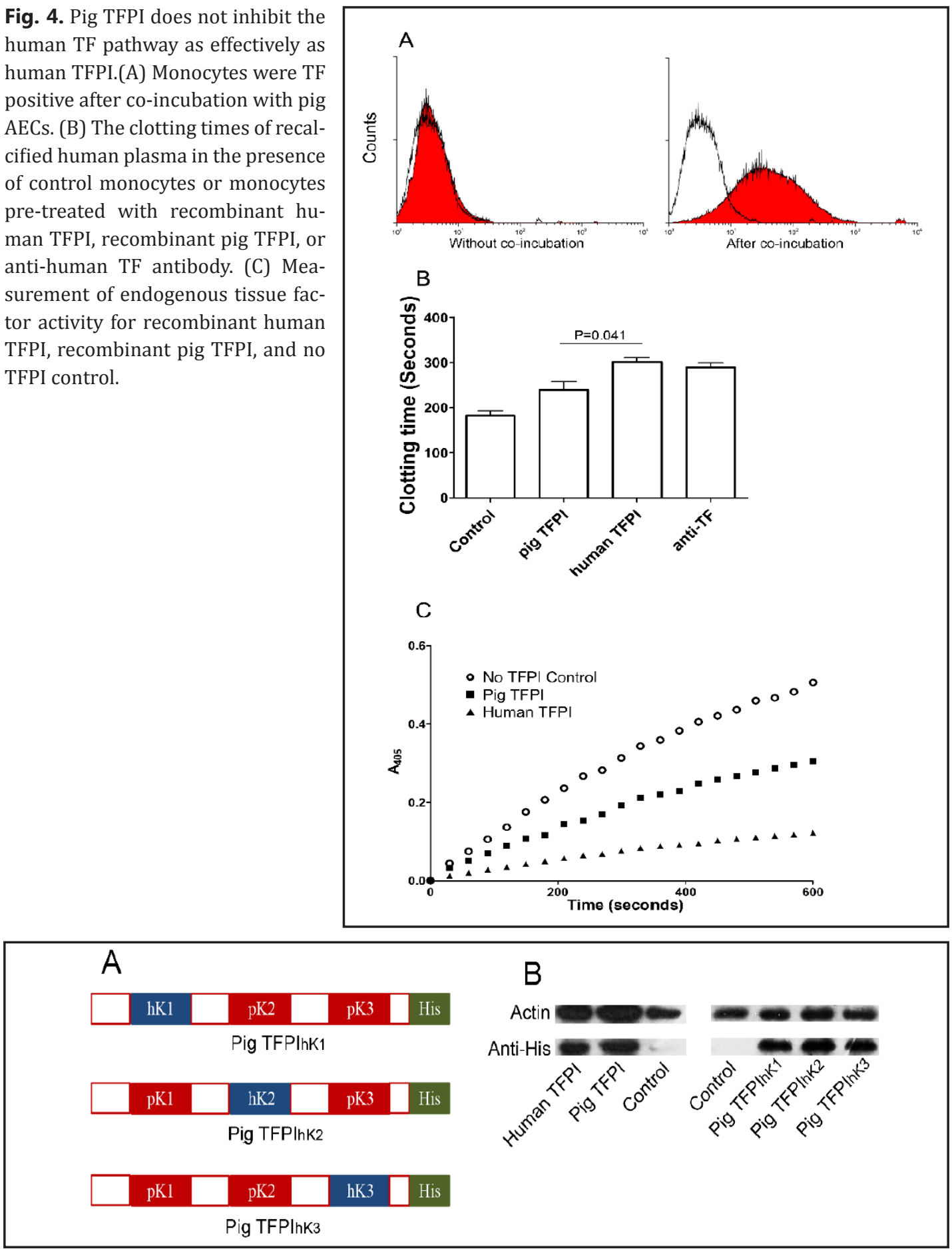

Fig. 5. Comparison of the TFPI coding sequences and structure of chimeric TFPI proteins.(A) Chimeric pig TFPI proteins were constructed using human Kunitz domain sequences (hK1, hK2, hK3) to replace the corresponding pig sequences (pK1, pK2, pK3). (B) Chimeric proteins, recombinant human TFPI, and recombinant pig TFPI were verified by western blotting with an anti-His antibody.

BMSCs showed a strong ability to proliferate (Fig. 7B), and no morphological differences were observed before or after SV40T transfection using light microscopy (Fig. 7C).

To further demonstrate that immortalised BMSCs had the same phenotype as primary BMSCs, the cells were analysed for the expression of CD29, CD90, CD105, CD80, CD34, 


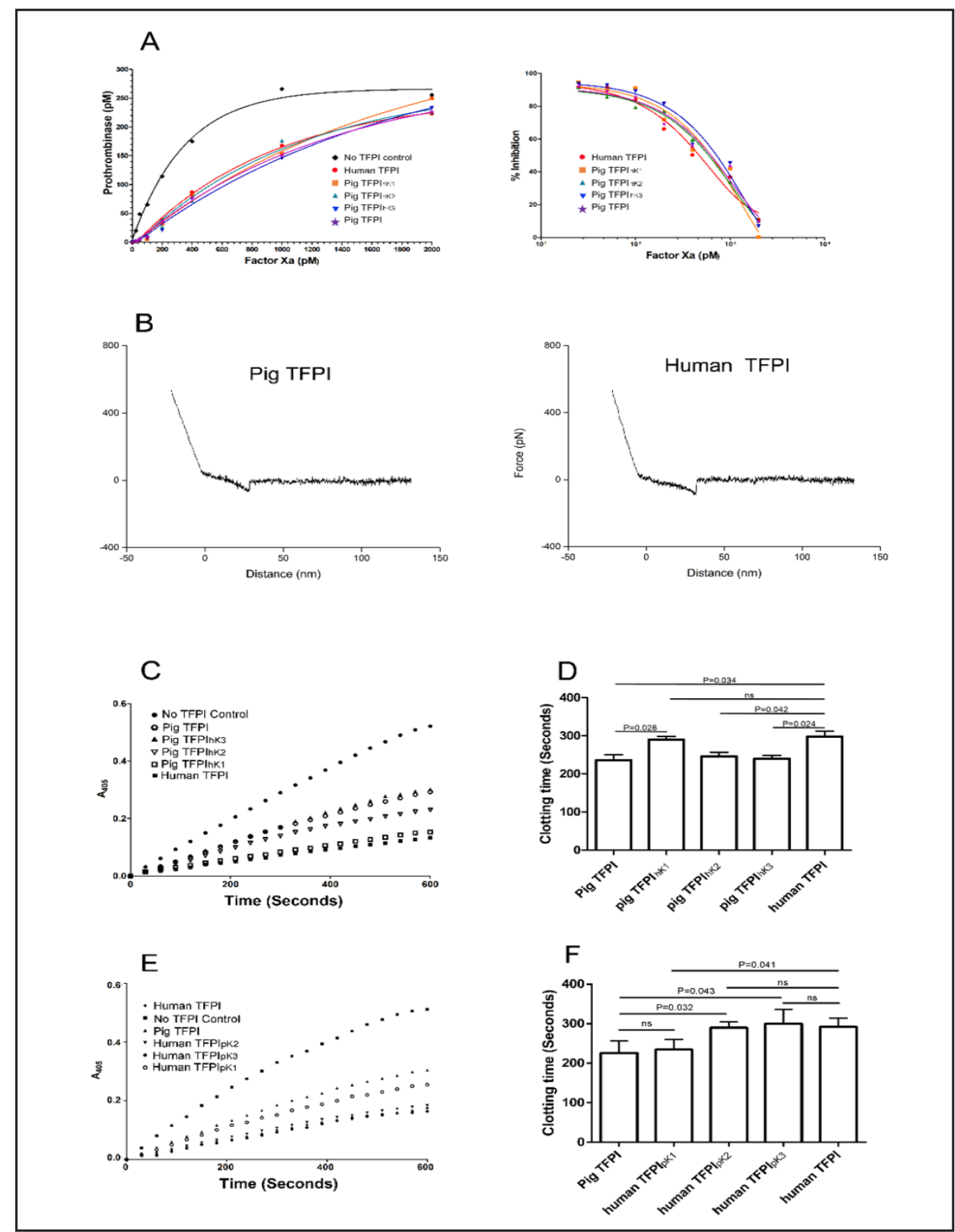

Fig. 6. Pig TFPI Kunitz domain 2 binds human FXa, but pig Kunitz domain 1 does not effectively inhibit human TF/FVIIa. (A) Pig TFPI ${ }_{\mathrm{hK} 1}, \mathrm{TFPI}_{\mathrm{hK} 2}, \mathrm{TFPI}_{\mathrm{hK} 3}$, human TFPI, and pig TFPI have a similar capacity to bind human FXa. Left: TFPI inhibition of thrombin generation by human FXa. Right: The efficiency of inhibition compared with the no TFPI control. (B) Intermolecular forces between human FXa and human TFPI (left)

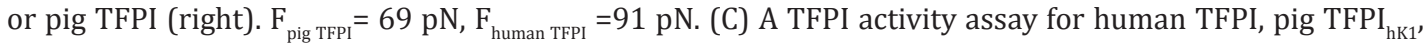
pig TFPI $_{\mathrm{hK} 2}$, pig TFPI $_{\mathrm{hK} 3}$, and pig TFPI. (D) Recalcification clotting assay for monocytes pre-incubated with pig TFPI, pig TFPI ${ }_{\mathrm{hK} 1}$, pig TFPI ${ }_{\mathrm{hK} 2}$, pig TFPI ${ }_{\mathrm{hK} 3}$, and human TFPI. (E) A TFPI activity assay for human TFPI, human $\mathrm{TFPI}_{\mathrm{pK} 1}$, human $\mathrm{TFPI}_{\mathrm{pK} 2}$, human $\mathrm{TFPI}_{\mathrm{pK} 3}$, and pig TFPI. (F) A recalcification clotting assay for monocytes pre-incubated with pig TFPI, human TFPI, human TFPI ${ }_{\mathrm{pK} 1}$, human TFPI ${ }_{\mathrm{pK} 2}$, human TFPI ${ }_{\mathrm{pK} 3}$ and human TFPI. 
Fig. 7. The characteristics of pig BMSCs after immortalisation by SV40T transfection. (A) RT-PCR amplification of SV40T mRNA from primary cells, lentiviral vector-transfected cells, and immortalised cells. (B) MTT proliferation assay. (C) Morphological characteristics of primary cells (left) and immortalised cells (right) as viewed by light microscopy (100x). (D) Flow cytometry of immortalised cells. (E) Differentiation assays of primary and immortalised cells. Left: oil red-O staining after adipogenic differentiation culture. Right: silver nitrate staining after osteogenic differentiation culture (200x).

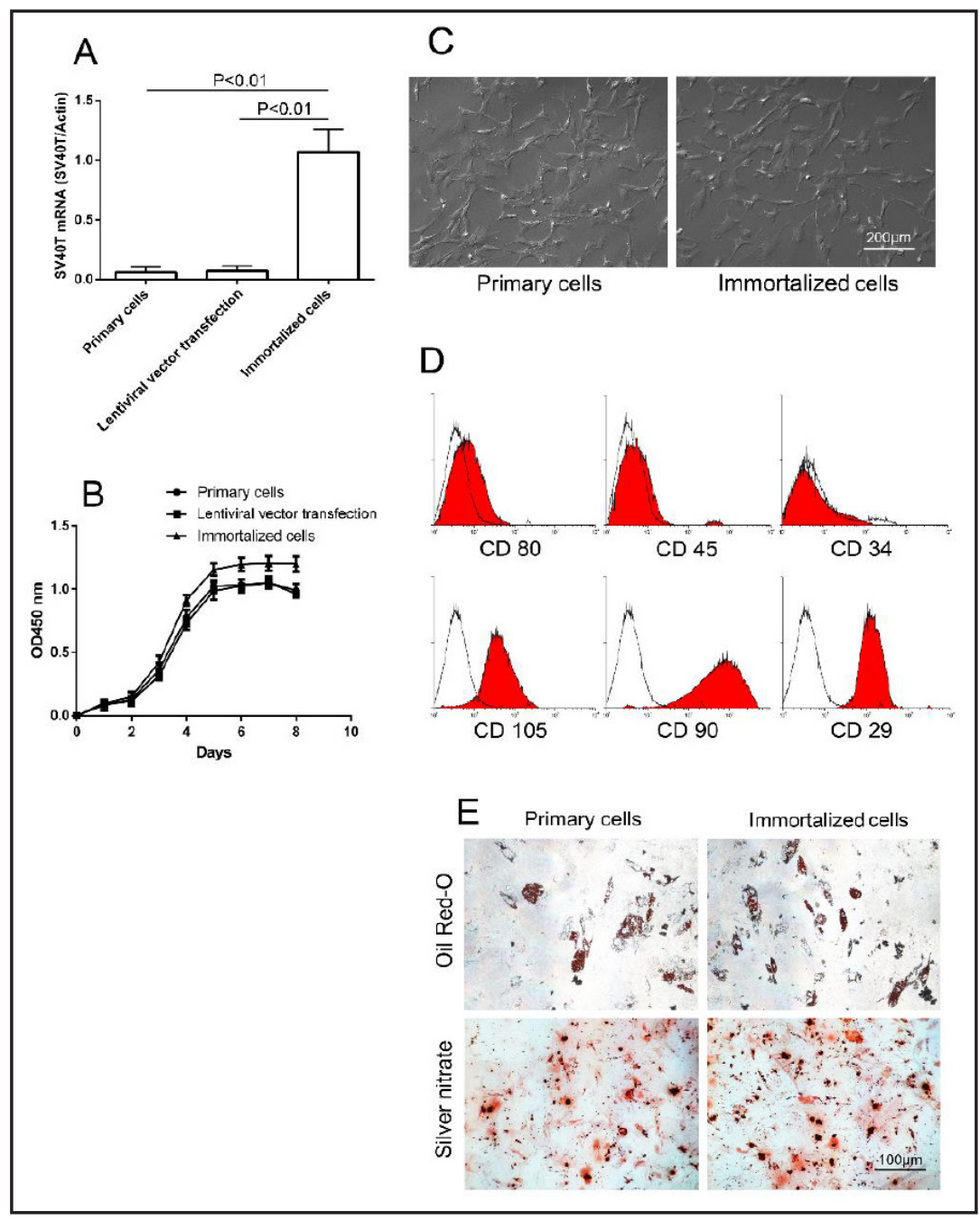

and CD45 by flow cytometry. Transfected cells were positive for CD29, CD90, and CD105 and negative for CD80, CD34, and CD45 (Fig. 7D), which was the same profile described previously for primary cells [24]. In addition, immortalised BMSCs were cultured in MSC osteogenic differentiation medium or adipogenic differentiation medium for 28 days to determine the effect of SV40T transfection on BMSC differentiation. BMSCs were then stained with silver nitrate (osteogenic culture) or oil red-0 (adipogenic culture). SV40T-transfected cells showed the same differentiation ability as primary cells (Fig. 7E).

\section{Lentivirus-mediated transfection enables pig BMSCs to express human TFPI}

After pig BMSCs were immortalised, a lentiviral vector was used to transfect human TFPI into pig BMSCs. The human TFPI sequence was inserted into pGMLV-PA5 to generate the recombinant lentivirus. Human TFPI mRNA expression was detected with real-time PCR from passage 0 (before transfection) to passage 7. A significant, stable rise in TFPI mRNA was observed after transfection (Fig. 8A). Western blotting (Fig. 8B) and immunohistochemistry (Fig. 8C) were used to confirm the up regulation of TFPI after transfection.

\section{Human TFPI-transfected pig BMSCs inhibit the TF pathway in vitro}

The TFPI activity assay and human plasma recalcification assay were used to examine the efficacy of human TFPI in transfected pig BMSCs. The inhibition of TF activation with human TFPI-transfected BMSCs was similar to that using recombinant human TFPI (Fig. 9A). Furthermore, pretreatment with anti-human TFPI restored TF activation to a level that 
Fig. 8. Human TFPI is expressed on pig BMSCs after lentiviral transfection. (A) Real-time PCR of TFPI mRNA in pig BMSCs before (generation 0) and after (generations 1-7) human TFPI transfection. (B) Western blot assay showing strong up regulation of human TFPI in transfected pig BMSCs. (C) Strong surface expression of human TFPI was detected after transfection (right) compared with control (left) (200x). (The control in all of the panels is SV40T-transfected, TFPI-untransfected pig BMSCs.) $\left({ }^{*} p<0.01\right.$ vs. before transfection).

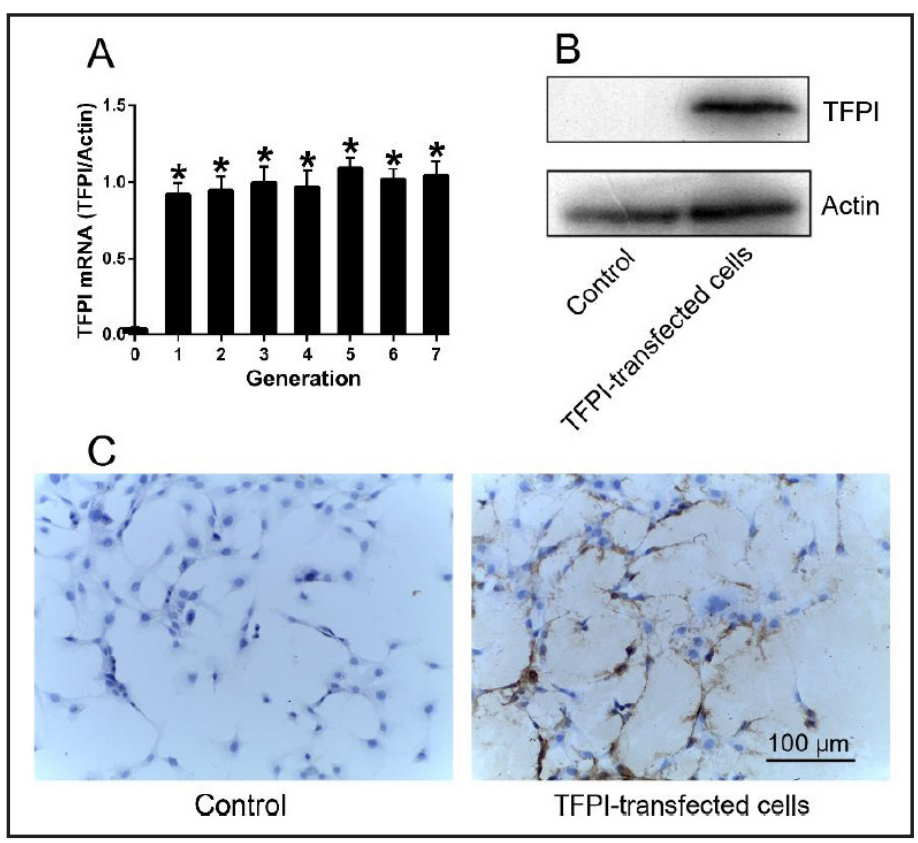

was similar to vector-transfected and untransfected BMSCs. Human monocytes were first co-incubated with pig AECs for 8 hours, then isolated and co-incubated with pig BMSCs for another 4 hours. Compared with lentiviral vector-transfected pig BMSCs, a significant inhibition of clotting was observed using human TFPI-transfected pig BMSCs (182 \pm 21 vs. $293 \pm 12$ seconds, respectively, $t=6.609, \mathrm{P}=0.003, \mathrm{n}=3$, Fig. 9B). The inhibition was significantly weaker when human TFPI-transfected pig BMSCs were pretreated with anti-human TFPI ( $215 \pm 14$ seconds, $\mathrm{t}=5.847, \mathrm{P}=0.004, \mathrm{n}=3$ ).

To evaluate the effect of the human TFPI-transfected pig BMSCs on clotting, a mouse model was used, in which haeme was employed to induce the expression of TF. After the injection of haeme, a reduction in the clotting time ( $74 \pm 19$ seconds) was observed in mice compared to mice without a haeme injection $(120 \pm 15$ seconds, $t=3.219, \mathrm{P}=0.030, \mathrm{n}=3)$. Then, human TFPI-transfected pig BMSCs were injected via the tail vein of the mice. In the mouse plasma recalcification assay, a prolongation of clotting time was observed in mice injected with the transgenic pig BMSCs ( $\mathrm{t}=3.213, \mathrm{P}=0.033, \mathrm{n}=3$, compared with haeme-injected mice) but not in mice injected with untreated pig BMSCs (80 \pm 11 seconds), normal saline $(76 \pm 17$ seconds) or lentiviral vector ( $72 \pm 19$ seconds) (normal saline: $\mathrm{t}=0.136, \mathrm{P}=0.899, \mathrm{n}=3$; pig BMSCs: $\mathrm{t}=0.473, \mathrm{P}=0.661, \mathrm{n}=3$; lentiviral vector: $\mathrm{t}=0.129, \mathrm{P}=0.904, \mathrm{n}=3$, all compared with haeme-injected mice, Fig. 9C).

\section{Discussion}

Dysregulated coagulation is a major cause of graft loss in xenotransplantation [25]. Coagulation dysregulation after transplantation is associated with the activation of TF. Our initial observations in this study suggest that activated TF after pig-to-primate xenotransplantation originates from the recipient. When we next examined why recipient $\mathrm{TF}$ was not inhibited efficiently, we identified a species incompatibility between human TF and pig TFPI, with Kunitz domain 1 playing the most important role in the incompatibility. As a first step in solving this incompatibility, we developed pig BMSCs that express human TFPI and demonstrated their ability to inhibit human TF in vitro.

Previous studies showed that $\mathrm{TF}$ activated by the immune response (IR) in donor livers is the main cause of coagulation dysregulation [5, 7, 8]. Ekser et al. [8] showed that recipient $\mathrm{TF}$ on recipient monocytes is activated earlier than $\mathrm{TF}$ on donor livers after liver xenotransplantation. In our current study, we established a new liver xenotransplantation 

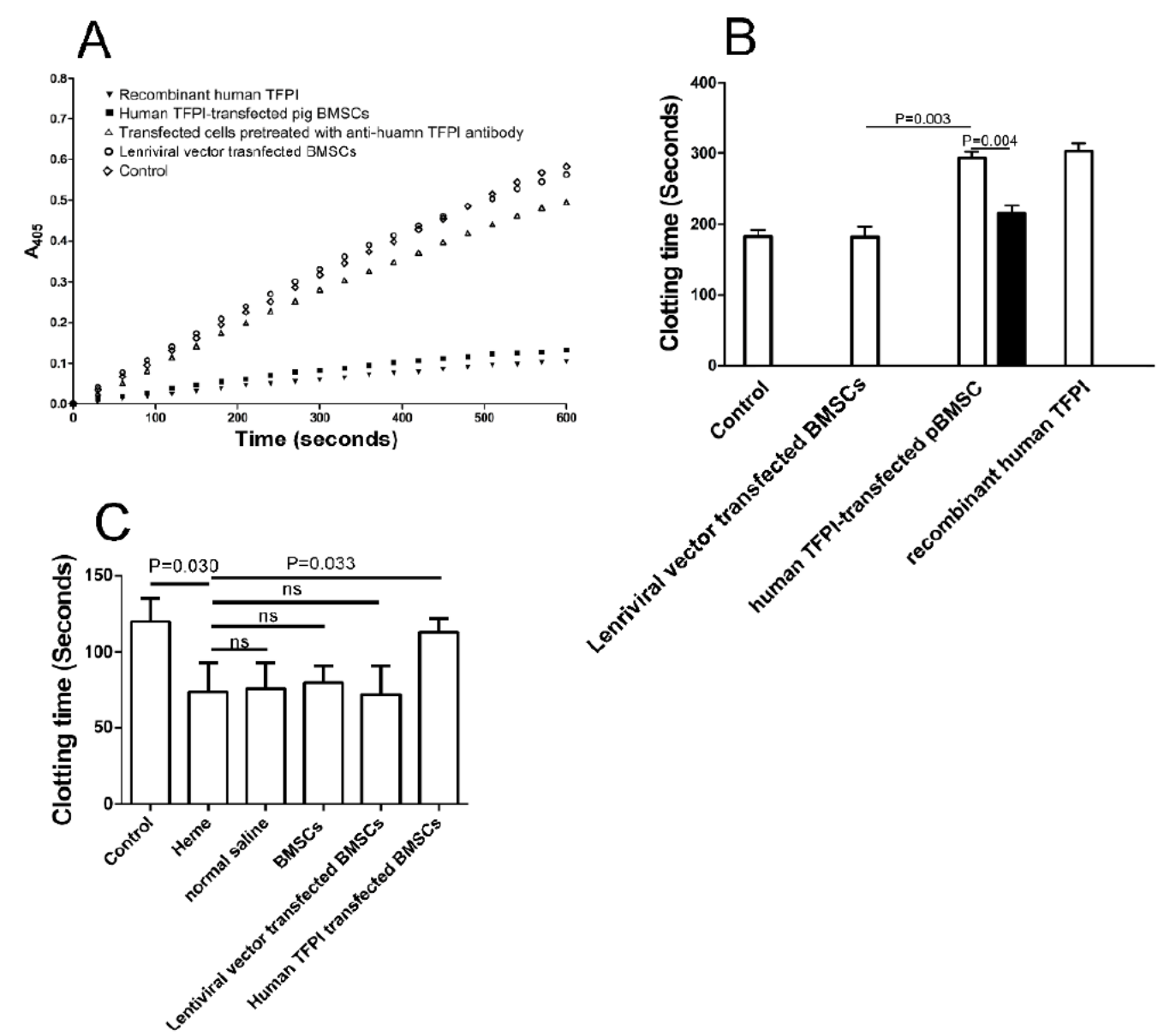

Fig. 9. Human TFPI-transfected pig BMSCs inhibit clotting in vitro and in a rodent model.(A) A TFPI activation assay with recombinant human TFPI, human TFPI-transfected pig BMSCs, human TFPI-transfected pig BMSCs pretreated with anti-human TFPI, lentiviral vector-transfected immortalised pig BMSCs, and untreated immortalised pig BMSCs. (B) A recalcification assay. Human monocytes were co-incubated with pig AECs (pAECs), and then co-incubated with or without human TFPI-transfected pig BMSCs (pBMSCs) or lentiviral vector-transfected immortalised BMSCs. The activity was compared to monocytes treated with pAECs followed by recombinant human TFPI. Closed bar: human TFPI-transfected pig BMSCs pretreated with anti-human TFPI. (C) The recalcification of mice that, without treatment, induced TF activation by injecting TF, and the TF-activated mice injected with normal saline, lentiviral vector and human TFPI-transfected pig BMSCs.

model to investigate the roles of recipient and donor livers. The recipient in this study showed nearly the same changes in coagulation as when the recipient liver is removed [5,17]. Our comparison of recipient organs and donor livers provides more evidence that recipient $\mathrm{TF}$ is activated earlier after transplantation than TF from the donor liver. Recipient TF activation and the occurrence of CC were synchronised. Furthermore, we found no evidence that the activation of donor TF was correlated with the initiation of coagulation dysregulation.

These results were consistent with those of Lin et al. [11]. In both studies, the native organs were more likely to express TF than donor organs after xenotransplantation. Moreover, in Lin's study, the activation of platelets and its "cross-talk" with leukocytes seems to play an important role in the induction of CC. Likewise, in our study, the activation of monocytes was also observed in recipients when CC occurred. It seems that TF activation after xenotransplantation is a systemic response in recipients. In both studies, recipient 


\section{Cellular Physiology Cell Physiol Biochem 2015;36:233-249 \\ \begin{tabular}{l|l|l|} 
DOI: 10.1159/000374067 & (0 2015 S. Karger AG, Basel
\end{tabular} \\ www.karger.com/cpb \\ Hongchen et al.: Coagulation Dysregulation due to Xenotransplantation}

$\mathrm{TF}$, rather than donor $\mathrm{TF}$, was activated once $\mathrm{CC}$ occurred. It is a reasonable speculation that recipient TF may correlate with CC after xenotransplantation. Furthermore, our study demonstrates that inhibiting the activation of recipient TF may provide a meaningful method for controlling coagulation dysregulation.

Our study also suggests that failure to inhibit the activation of recipient TF was due to species incompatibility of pig TFPI and that Kunitz domain 1 plays the most important role in this incompatibility. Pig TFPI Kunitz domain 2 also affected the inhibition of human TF but not as significantly as domain 1 , possibly due to the difference in the binding strength between FXa and human versus pig TFPI. We found no evidence that the Kunitz domain 3 plays a role in species incompatibility by binding to the cell surface GPI anchor through coreceptors. As the co-receptors for TFPI binding to the cell surface are not entirely known [10], the role of their interaction with TFPI in species incompatibility requires further study.

Other groups have shown different results in studies of the incompatibility of pig TFPI. Kopp [15] showed that pig TFPI on pig AECs fails to bind human FXa and thus fails to inhibit human TF/FVIIa. Cultured pig AECs may express considerably lower levels of firmly attached TFPI on their surface than human AECs [16]. Lee showed that recombinant pig TFPI binds human FXa and efficiently inhibits human TF/FVIIa, perhaps because of their use of the FLAG tag as an indirect way to test TFPI expression on the cell surface. The differences in the assays used may have caused the contrasts between the studies. Because TFPI is glycosylated in the ER and usually functions on the cell surface, the use of cell free and non-glycosylated TFPI in the TFPI assay has the potential to be a factor that influences the results. Regardless, the overexpression of human TFPI here contributed to the regulation of coagulation, as shown with cardiac xenotransplantation [26].

What is the best way to overexpress human TFPI in pig-to-primate liver xenotransplantation recipients? The injection of exogenous recombinant TFPI may not be efficient because free TFPI in the plasma can be degraded by a variety of proteinases [12], and the co-receptor binds to TFPI in the endoplasmic reticulum/Golgi only inside cells [13]. Another possible option is breeding donor pigs transfected with human TFPI. However, transgenic pigs with other genes, such as CD46, CD55, CD59, and thrombomodulin, have also shown a potential to prolong survival following xenotransplantation [27-30]. In such cases, we developed donor human TFPI-transfected BMSCs as an alternative way to overexpress human TFPI in xenotransplantation when pigs transfected with other genes (without TFPI) were used as donors. BMSCs were chosen to be the carriers of the genes due to their adequate availability, easy accessibility, rapid proliferation, and successful integration and immunological tolerance in the host tissue [24]. Our human TFPI-transfected pig BMSCs showed high-efficiency binding of human FXa and inhibited TF/FVIIa in vitro and in a rodent model, demonstrating that they are effective gene carriers. Jie et al. [31] showed that the survival of pig-to-rhesus xenografts is prolonged by prior donor bone marrow transplantation. Further studies showed that BMSCs can induce immunosuppression by inhibiting the proliferation of $\mathrm{T}$ cells and the secretion of immunosuppressive factors such as interleukin-10 and transforming growth factor $\beta$ [32-36]. This result has been further demonstrated in xenotransplantation models using donor BMSCs co-transplanted with the liver or cellular nerve grafts $[32,36]$. Obviously, the movement, attachment, and differentiation of BMSCs and the expression of TFPI and its effect on the coagulation need to be evaluated in vivo. Moreover, the use of GTKO pigs expressing human complement and coagulation regulatory proteins would be more contemporary as they are able to eliminate "noise" caused by other pathways. These types of experiments would be considered in our future studies.

In summary, early activation of recipient TF is responsible for coagulation dysregulation after liver transplantation. The incompatibility between pig TFPI and human TF leads to the inefficient inhibition of recipient TF. The overexpression of human TFPI by pig BMSCs inhibits clotting in vitro. Our results offer a predictable approach to addressing the problem of coagulation dysregulation after xenotransplantation. This approach will be investigated in our in vivo xenotransplantation model. 


\begin{tabular}{rl|l} 
Cellular Physiology & \multicolumn{1}{c}{ Cell Physiol Biochem 2015;36:233-249 } \\
and Biochemistry & $\begin{array}{l}\text { DOI: 10.1159/000374067 } \\
\text { Published online: May 04, 2015 }\end{array}$ & $\begin{array}{l}\text { O 2015 S. Karger AG, Basel } \\
\text { www.karger.com/cpb }\end{array}$ \\
\cline { 2 - 3 } & Hongchen et al:: Coagulation Dysregulation due to Xenotransplantation
\end{tabular}

\section{Acknowledgements}

These experiments were supported by the National Basic Research Program of China (973 Program; 2015CB554100), the National Natural Science Foundation (81270549 and 81300361), the XiJing Hospital disciplines boosting project (XJZT12M09), the Xijing Hospital disciplines boosting project (XJZT13Z01), the Science and Technology Research and Development Program of Shaanxi province (2013K12-18-02) and the National High Technology Research and Development Program (863 Program; 2012AA021005).

\section{Disclosure Statement}

There are no conflicts of interest in this work.

\section{References}

1 Ekser B, Ezzelarab M, Hara H, van der Windt DJ, Wijkstrom M, Bottino R, Trucco M, Cooper DK: Clinical xenotransplantation: the next medical revolution? Lancet 2012;379:672-683.

2 Cooper DKC, Gollackner B, Sachs DH: Will the pig solve the transplantation backlog? Annu Rev Med 2002;53:133-147.

3 Bush EL, Barbas AS, Holzknecht ZE, Byrne GW, McGregor CG, Parker W, Davis RD, Lin SS: Coagulopathy in $\alpha$-galactosyl transferase knockout pulmonary xenotransplants. Xenotransplantation 2011;18:6-13.

4 Mueller NJ, Ezzelarab M, Buhler L, Haeberli L, Ayares D, Cooper DKC: Monitoring of porcine and baboon cytomegalovirus infection in xenotransplantation. Xenotransplantation 2009;16:535-536.

5 Ekser B, Cooper DK: Overcoming the barriers to xenotransplantation: prospects for the future. Expert Rev Clin Immunol 2010;6:219-230.

6 Lin CC, Chen D, McVey JH, Cooper DK, Dorling A: Expression of tissue factor and initiation of clotting by human platelets and monocytes after incubation with porcine endothelial cells. Transplant 2008;86:702709.

7 Nagayasu T, Saadi S, Holzknecht RA, Plummer TB, Platt JL: Expression of tissue factor mRNA in cardiac xenografts: clues to the pathogenesis of acute vascular rejection. Transplant 2000;69:475-482.

8 Ekser B, Lin CC, Long C, Echeverri GJ, Hara H, Ezzelarab M, Bogdanov VY, Stolz DB, Enjyoji K, Robson SC, Ayares D, Dorling A, Cooper DK, Gridelli B: Potential factors influencing the development of thrombocytopenia and consumptive coagulopathy after genetically modified pig liver xenotransplantation. Transpl Int 2012;25:882-896.

9 Cowan PJ, Roussel JC, d'Apice AJ: The vascular and coagulation issues in xenotransplantation. Curr Opin Organ Transplant 2009;14:161-167.

10 Lin CC, Ezzelarab M, Hara H, Long C, Lin CW, Dorling A, Cooper DK: Atorvastatin or transgenic expression of TFPI inhibits coagulation initiated by anti-nonGal IgG binding to porcine aortic endothelial cells. J Thromb Haemost 2010;8:2001-2010.

11 Lin CC, Ezzelarab M, Shapiro R, Ekser B, Long C, Hara H, Echeverri G, Torres C, Watanabe H, Ayares D, Dorling A, Cooper DK: Recipient tissue factor expression is associated with consumptive coagulopathy in pig-to-primate kidney xenotransplantation. Am J Transplant 2010;10:1556-1568.

12 Broze GJ Jr, Girard TJ: Tissue factor pathway inhibitor: structure-function. Front Biosci 2012;17:262-280.

13 Maroney SA, Cunningham AC, Ferrel J, Hu R, Haberichter S, Mansbach CM, Brodsky RA, Dietzen DJ, Mast AE: A GPI-anchored co-receptor for tissue factor pathway inhibitor controls its intracellular trafficking and cell surface expression. J Thromb Haemost 2006;4:1114-1124.

14 Mast AE, Acharya N, Malecha MJ, Hall CL, Dietzen DJ: Characterization of the association of tissue factor pathway inhibitor with human placenta. Arterioscler Thromb Vasc Biol 2002;22:2099-2104.

15 Kopp CW, Siegel JB, Hancock WW, Anrather J, Winkler H, Geczy CL, Kaczmarek E, Bach FH, Robson SC: Effect of porcine endothelial tissue factor pathway inhibitor on human coagulation factors. Transplant 1997;63:749-758.

16 Lee KF, Salvaris EJ, Roussel J, Robson SC, dApice AJF, Cowan PJ: Recombinant pig TFPI efficiently regulates human tissue factor pathways. Xenotransplantation 2008;15:191-197. 
17 Kim K, Schuetz C, Elias N, Veillette GR, Wamala I, Varma M, Smith RN, Robson SC, Cosimi AB, Sachs DH, Hertl M: Up to 9-day survival and control of thrombocytopenia following alpha 1, 3-galactosyl transferase knockout swine liver xenotransplantation in baboons. Xenotransplantation 2012;19:256-264.

18 Han W, Zhou J, Li X, Wang J, Li J, Zhang Z, Yang Z, Wang D, Tao K, Dou K: RNA interference of GGTA1 physiological and immune functions in immortalized porcine aortic endothelial cells. Journal of Surgical Research. 2013;185:410-418.

19 Kopp CW, Robson SC, Siegel JB, Anrather J, Winkler H, Grey S, Kaczmarek E, Bach FH, Geczy CL: Regulation of monocyte tissue factor activity by allogeneic and xenogeneic endothelial cells. Thromb Haemost 1998;79:529-538.

20 Ehrnfelt C, He Z, Holgersson J: No role of alpha-Gal in human b monocyte-endothelial cell interactions in vitro. Scand J Immunol 2005;62:445-452.

21 Fang X, Mu Y, Huang Z, Li Y, Han L, Zhang Y, Feng Y, Chen Y, Jiang X, Zhao W, Sun X, Xiong Z, Yang L, Liu H, Fan D, Mao L, Ren L, Liu C, Wang J, Li K, Wang G, Yang S, Lai L, Zhang G, Li Y, Wang J, Bolund L, Yang H, Wang J, Feng S, Li S, Du Y: The sequence and analysis of a Chinese pig genome. GigaScience 2012;1:16.

22 van't Veer C, Mann KG: Regulation of tissue factor initiated thrombin generation by the stoichiometric inhibitors tissue factor pathway inhibitor, antithrombin-III, and heparin cofactor-II. J Biol Chem 1997;272:4367-4377.

23 Sparkenbaugh EM, Chantrathammachart P, Wang S, Jonas W, Kirchhofer D, Gailani D, Gruber A, Kasthuri R, Key NS, Mackman N, Pawlinski R.: Excess of heme induces tissue factor-dependent activation of coagulation in mice. Haematologica Doi:10.3324/haematol.2014.114728.

24 Ji R, Zhang N, You N, Li Q Liu W, Jiang N, Liu J, Zhang H, Wang D, Tao K, Dou K: The differentiation of MSCs into functional hepatocyte-like cells in a liver Biomatrix scaffold and their transplantation into liver-fibrotic mice. Biomaterials 2012;33:8995-9008.

25 Cowan PJ, d'Apice AJ: The coagulation barrier in xenotransplantation: incompatibilities and strategies to overcome them. Curr Opin Organ Transplant 2008;13:178-183.

26 Chen D, Weber M, McVey JH, Kemball-Cook G, Tuddenham EG, Lechler RI, Dorling A: Complete inhibition of acute humoral rejection using regulated expression of membrane-tethered anticoagulants on xenograft endothelium. Am J Transplant 2004;4:1958-1963.

27 LaMattina JC, Burdorf L, Zhang T, Rybak E, Cheng X, Munivenkatappa R, Salles II, Broos K, Sievert E, McCormick B, Decarlo M, Ayares D, Deckmyn H,Azimzadeh AM, Pierson RN 3rd, Barth RN: Pig-to-baboon liver xenoperfusion utilizing GalTKO. hCD46 pigs and glycoprotein Ib blockade. Xenotransplantation 2014;21:274-286.

28 Wuensch A, Baehr A, Bongoni AK, Kemter E, Blutke A, Baars W, Haertle S, Zakhartchenko V, Kurome M, Kessler B, Faber C, Abicht JM, Reichart B, Wanke R,Schwinzer R, Nagashima H, Rieben R, Ayares D, Wolf E, Klymiuk N: Regulatory sequences of the porcine THBD gene facilitate endothelial-specific expression of bioactive human thrombomodulin in single- and multi transgenic pigs. Transplantation 2014;97:138-147.

29 Mohiuddin MM, Singh AK, Corcoran PC, Hoyt RF, Thomas ML, Ayares D, Horvath KA: Genetically engineered pigs and target-specific immunomodulation provide significant graft survival and hope for clinical cardiac xenotransplantation. J Thorac Cardiovasc Surg 2014;148:1106-1114.

30 Chen Y, Stewart JM, Gunthart M, Hawthorne WJ, Salvaris EJ, O'Connell PJ, Nottle MB, d'Apice AJ, Cowan PJ, Kearns-Jonker M: Xeno antibody response to porcine islet cell transplantation using GTKO, CD55, CD59, and fucosyltransferase multiple transgenic donors. Xenotransplantation 2014;21:244-253.

31 Jie Y, Liu L, Pan Z, Wang L: Survival of pig-to-rhesus corneal xenografts prolonged by prior donor bone marrow transplantation. Mol Med Rep 2013;7:869-874.

32 Cho K, Ju S, Cho SJ, Jung Y, Woo S, Seoh J, Han HS, Ryu KH: Mesenchymal stem cells showed the highest potential for the regeneration of injured liver tissue compared with other subpopulations of the bone marrow. Cell Biol Int 2009;33:772-777.

33 Hong ZF, Huang XJ, Yin ZY, Zhao WX, Wang XM: Immunosuppressive function of bone marrow mesenchymal stem cells on acute rejection of liver allografts in rats. Transplant Proc 2009;41:403-409.

34 Ma S, Xie N, Li W, Yuan B, Shi Y, Wang Y: Immunobiology of mesenchymal stem cells. Cell Death Differ 2014;21:216-225.

35 Wang JW, Liu YB, Xu B, Li JT, Qian HR, Zhang M, Peng SY: The study on immunomodulation of donor mesenchymal stem cells on discordant liver xenotransplantation. Chinese Journal of Surgery 2005;43:1254-1258.

36 Fan L, Yu Z, Li J, Dang X, Wang K: Immunoregulation effects of bone marrow-derived mesenchymal stem cells in xenogeneic acellular nerve grafts transplant. Cell Mol Neurobiol 2014;34:999-1010. 